\title{
POLÍTICAS PÚBLICAS DE TRABALHO NO BRASIL
}

\author{
WORK: PUBLIC POLICIES IN BRAZIL
}

\author{
José Aparecido dos Santos*
}

\begin{abstract}
RESUMO: as políticas públicas de trabalho no Brasil quase sempre se pautaram pela tentativa de fornecimento de mão de obra farta e barata, de início para as elites agrárias, depois para o incipiente capital industrial. Tanto o escravagismo como as políticas de imigração estiveram vinculadas a essa finalidade. A posterior legislação social, entretanto, assumiu o caráter contraditório das transformações sociais e econômicas do século $\mathrm{XX}$, e de suas bases autoritárias adquiriu um conteúdo emancipador. A fragmentação e a redução quantitativa e qualitativa do trabalho dos tempos atuais exigem novas formas de proteção social, para além da cidadania salarial, de modo a incorporar aqueles que, supostamente autônomos, encontram-se sob profunda dependência estrutural. É necessário atribuir espaço público para atividades que ainda não possuem relevância simbólica e que demandam novas formas de solidariedade social. É nessa perspectiva que programas de renda social devem ser concebidos.
\end{abstract}

PALAVRAS-CHAVE: Políticas públicas. Renda social. Trabalho.

ABSTRACT: The Brazilian public policies related to labor were usually guided by the attempt to supply cheap and plentiful manpower, firstly for rural elites, then for the incipient industrial capital. Both slavery and immigration policies were linked to this purpose. However, the subsequent social legislation took on the contradictory character of social and economic transformations of the twentieth century and from its authoritarian bases acquired an emancipatory content. The nowadays fragmentation and reduction of the work, both quantitative and qualitative, requires new forms of social protection, in addition to the wagebased citizenship, in order to incorporate those supposedly autonomous workers, which are found under deep structural dependency. It is necessary to allocate public space for activities that still do not have symbolic relevance and that demand new forms of social solidarity. It is in this perspective that social income programs should be designed.

KEYWORDS: Public policies. Social income. Work.

\section{INTRODUÇÃO}

Políticas públicas é um termo plurissignificante e ainda impreciso. Embora tenha passado a ser utilizado mais recentemente, trata-se de uma expressão diretamente ligada à

\footnotetext{
* Mestre e Doutor em Direito pela Pontifícia Universidade Católica do Paraná e Juiz Titular da $17^{\mathrm{a}}$ Vara do Trabalho de Curitiba. Bolsista da CAPES - Proc. $\mathrm{n}^{\circ}$ BEX 10687/12-2. E-mail: joseaparecidodossantos@ymail.com
} 
modernidade, pois reflete anseios de previsibilidade e calculabilidade da atividade política, por meio de controles normativos. Adotar políticas públicas significa acreditar na ideia de progresso ou de desenvolvimento social e, ao mesmo tempo, na possibilidade de prever eventuais resultados de programas normativos complexos.

Em caráter provisório, é possível defini-las como um conjunto de ações estatais, inclusive de caráter normativo, que busca obter participação da sociedade civil no atingimento dos objetivos constitucionais fundamentais da República (BRASIL, 1988, art. $3^{\circ}$ ). A partir dessa definição, creio que seja possível afirmar que as primeiras ou as principais políticas públicas adotadas no Brasil sempre estiveram relacionadas de modo direto ou indireto ao trabalho. Desde a Independência até hoje, inúmeras foram as ações estatais que visavam resolver problemas de mão de obra no País. Essas ações desde cedo contaram com considerável participação da sociedade civil, seja porque afetavam grupos, seja porque decorriam de ou se refletiam em relações econômicas empresariais.

Não poderia ser diferente, pois o trabalho é uma categoria central do capitalismo, de sorte que sempre foi importante criar as condições elementares de acumulação, principalmente o fornecimento de mão de obra abundante, de boa qualidade e barata. A necessidade de fornecer essa matéria-prima elementar sempre esteve na base de todas as políticas públicas adotadas no País.

O objetivo deste trabalho é efetuar um exame crítico das políticas públicas relacionadas ao trabalho na experiência histórica brasileira, para detectar suas principais características e permitir reflexão sobre novas possibilidades de políticas públicas de trabalho, em especial sobre a renda social mínima, e àqueles que não estejam em regime de trabalho assalariado.

\section{POLÍticas PÚbliCAS DE IMIGRAÇÃo E DE COLONIZAÇÃo - PERÍODO ATÉ 1930}

É comum se afirmar que as políticas públicas de trabalho começaram, no Brasil, com a Revolução de 1930. Essa afirmação, conquanto correta em certo aspecto, decorre de uma concepção mais restrita do que sejam políticas públicas. Consideradas em sentido amplo, é possível afirmar que mesmo no período imperial e na Primeira República havia políticas relacionadas ao trabalho.

Até meados do século XIX os meios de produção no Brasil estavam, quase que exclusivamente, orientados para a agricultura de exportação e utilizavam a mão de obra 
escrava. Por isso, as políticas adotadas pelo Estado brasileiro se pautavam, de início, pela preocupação com o bom e livre abastecimento proporcionado pelo tráfico negreiro. Surgia na primeira metade do século XIX alguma preocupação com o trabalho livre, mas é preciso contextualizar tais preocupações com o ambiente social e econômico em que foram produzidas. Ainda incipientes, essas preocupações com a criação de um mercado de trabalho livre estavam atreladas a três motivos. O primeiro era o iminente término da escravidão. As elites políticas e econômicas percebiam o fim próximo do regime de escravidão, incompatível com as modificações estruturais verificadas no capitalismo central. Ao mesmo tempo em que buscavam retardar ao máximo a abolição, as oligarquias sonhavam com a possibilidade de usar farta mão de obra europeia, tida como de melhor qualidade. O segundo correspondia à necessidade de colonizar o sul do País e as áreas de fronteira, pois os esforços anteriores de imigração tinham sido insuficientes. $O$ terceiro, de fundo racista, estava no desejo de branqueamento das estruturas sociais brasileiras ${ }^{1}$. Tudo isso explica a preocupação com a imigração de colonos em uma época em que ainda abundava a mão de obra escrava.

O trabalho livre era de pouca relevância econômica e de rara disciplina legislativa. A primeira lei que regulou os contratos de prestação de serviços de brasileiros e estrangeiros é de 13 de setembro de 1830. Essa Lei (BRASIL, 1830), de formato muito simples, era influenciada pelo regime hegemônico da época, o escravagista; tanto é verdade que estipulava, em seu artigo $2^{\circ}$, a possibilidade de se transferir o contrato de um para outro locador, bem como estipulava, nos artigos $3^{\circ}$ e $4^{\circ}$, que o trabalhador não poderia se negar a prestar serviços enquanto o locador cumprisse sua obrigação, exceto se pagasse metade do que receberia caso fosse cumprido o restante do contrato. $\mathrm{O}$ trabalhador que se evadisse do local da prestação de serviços seria preso e reconduzido até o locador para o cumprimento do contrato. Essas medidas foram consideradas insatisfatórias por muitos parlamentares conservadores, pois o objetivo expressamente defendido nos debates era o de prender os trabalhadores aos respectivos contratos, aspecto muito significativo na atividade canavieira, em que havia a possibilidade de trabalhadores mais especializados largarem o patrão em troca de uma melhor oferta.

À época em que foi editada a Lei de 1830 havia farta mão de obra escrava "devido à antecipação nas importações de escravos, pois os traficantes estavam se antecipando à lei de

\footnotetext{
${ }^{1}$ Esse sentido racista foi expressamente veiculado no Parlamento, conforme indica AZEVEDO (1987, p. 140-6). Tal desejo de branqueamento foi um dos motivos que tornou possível a Abolição, pois, em relação a muitos abolicionistas, "o que parece, à primeira vista, antiescravismo, é, a rigor, imigrantismo" (BOSI, 1992, p. 224. Grifo do autor).
} 
1831" (GEBARA, 1986, p. 78) ${ }^{2}$. Em decorrência das condições estruturais da época, a Lei de 13 de setembro de 1830 teve pouca repercussão na realidade social e foi incapaz de regular o mercado de trabalho livre. Embora não houvesse escassez de mão de obra, a edição dessa lei demonstrava preocupação com a diminuta entrada de estrangeiros no País.

As condições de fornecimento de mão de obra para a agricultura de exportação, entretanto, alteraram-se a partir das crescentes pressões inglesas contra o tráfico de escravos. A criação de políticas alternativas para o suprimento de mão de obra passou a ser cada vez mais importante, e o caminho imaginado pelas elites econômicas sempre foi o de importar mão de obra, principalmente a europeia. A mão de obra livre existente no País era considerada imprestável, embora, quantitativamente, não fosse desprezível. É nesse clima que, em 11 de outubro de 1837, foi promulgada a Lei 108 (BRASIL, 1837), que regulava exclusivamente os contratos de prestação de serviços de estrangeiros. Os trabalhadores brasileiros livres, cuja atividade pouco repercutia sobre a realidade socioeconômica, continuariam formalmente a se reger pela Lei de 13 de setembro de 1830, embora, na prática, suas atividades continuassem relevadas ao nível mínimo de subsistência em razão da "forma de inserção dessas populações à estrutura da sociedade brasileira, que as tornou marginais em relação ao sistema socioeconômico, numa terra farta e rica, e colocou-as, assim, a um só tempo, diante da quase impossibilidade e da quase desnecessidade de trabalhar" (FRANCO, 1983, p. 57).

A Lei de 1837 reconheceu juridicamente as sociedades de colonização, cujo objetivo era recrutar trabalhadores estrangeiros, inclusive menores de idade. Em relação aos menores a lei estabelecia, no artigo $6^{\circ}$, uma curiosa forma de mantê-los sob trabalho, pois metade do que ganhassem ficaria com o locatário ou com o juiz de órfãos, e seria entregue ao menor quando cessasse o serviço ou atingisse a maioridade. Essa lei era bem mais complexa que a de 1830 e previa, inclusive, dispensa com ou sem justa causa. Continuaram a ser estipuladas medidas coercitivas para o cumprimento dos contratos pelos trabalhadores, pois essa sempre foi a principal preocupação dos fazendeiros, entre as quais a obrigação, prevista no artigo $9^{\circ}$, de, em caso de rompimento sem justa causa do contrato, cada imigrante pagaria em dobro o que devia ao locatário, sob pena de prisão, ficando obrigado a servir "ao locatário de graça todo o tempo que faltar para o complemento do contrato". A declarada finalidade dessas regras era reaver, aos fazendeiros, o que haviam despendido para trazer os colonos imigrantes, mas tudo indica que o verdadeiro objetivo fosse manter o trabalhador preso ao prazo estipulado no

\footnotetext{
${ }^{2}$ Esse autor se refere à Lei de 7 de novembro de 1831 (BRASIL, 1831), que previa a liberdade de todos os escravos que desembarcassem no Brasil, conhecida como Lei de Proibição do Tráfico Negreiro.

Revista da Faculdade de Direito - UFPR, Curitiba, vol. 59, n. 3, p. 133-165, 2014.
} 
contrato, em quaisquer circunstâncias. Por isso, havia um instituto equivalente à carta de alforria, um salvo-conduto que obrigatoriamente o colono deveria portar e cuja falta "será razão suficiente para presumir-se que o locador se ausentou indevidamente" (BRASIL, 1837, art. 11).

A Lei de 1837 refletia a força coercitiva dos fazendeiros e reforçou no exterior a péssima imagem que se tinha a respeito das condições de trabalho no Brasil. Aprofundou-se a visão de um país selvagem e escravagista, de tal modo que não houve condições de se obter um número significativo de imigrantes regidos por aquela legislação. Moldadas em grande parte pelo regime da escravidão, constitutivo do imaginário do trabalho no País, as políticas de imigração adotadas não conseguiram atingir sua finalidade, pois sofreram a repulsa dos países europeus que possuíam mão de obra excedente. Não é acidental que essa lei tenha sido criada pelo governo da Segunda Regência Una, no início do período interino do Regente Pedro de Araújo Lima, do Partido Regressista (ultraconservador) ${ }^{3}$, que possuía ampla maioria no Parlamento. Os regressistas eram antiliberais e pretendiam estabelecer um protecionismo alfandegário, por meio de tarifas elevadas para os produtos importados.

Uma consequência curiosa da Lei de 1837 foi a estratégia de resistência adotada contra ela pelos estrangeiros. O contrato formal e escrito, previsto na lei e obtido muitas vezes à custa da ignorância ou da desambientação cultural do imigrante, escravizava os respectivos trabalhadores, de modo que, sempre que possível, os estrangeiros procuravam não lavrar contrato escrito, pois "a ausência de contrato assinado é um instrumento de pressão contra o empregador e de defesa do trabalhador" (GEBARA, 1986, p. 83). Essa resistência ao contrato escrito repercutiu nos custos de produção, o que tornou necessária a reforma realizada em 1879, quando a imigração se havia tornado imprescindível. Além disso, a contratação informal se disseminou de tal modo que, até hoje, transformou-se no modo natural de se prestar serviços no País.

O Código Comercial de 1850 (BRASIL, 1850), no título X (“Da locação mercantil”), artigos 226 a 246, passou a reger os contratos de locação de serviços e os de empreitada. A

\footnotetext{
${ }^{3}$ O Primeiro Regente Uno, Padre Feijó, renunciou em 19 de setembro de 1837, e a Lei 108 foi promulgada em 11 de outubro de 1837. Para se ter uma ideia da exclusão social e política da época, cite-se que Pedro de Araújo Lima (posteriormente Marquês de Olinda) foi eleito em caráter definitivo em 1838 com uma expressiva vitória de 4308 votos, muito superior aos 2826 votos obtidos por Feijó quatro anos antes. Estima-se que na época o País tivesse população de aproximadamente seis milhões de pessoas. Obviamente, essa disparidade da representação política era devida ao sistema censitário e à divisão dos parcos eleitores em eleitores de paróquia (renda anual mínima de 100.000 réis) e em eleitores de província (renda mínima de 200.000 réis), dos quais somente os últimos podiam ser eleitos senadores ou deputados. Tudo isso sem considerar as fraudes e violências praticadas durante as votações, que eram realizadas sempre depois da missa e dentro das igrejas.
}

Revista da Faculdade de Direito - UFPR, Curitiba, vol. 59, n. 3, p. 133-165, 2014. 
locação mercantil era definida como "o contrato pelo qual uma das partes se obriga a dar à outra, por determinado tempo e preço certo, o uso de alguma coisa, ou do seu trabalho" (BRASIL, 1850, art. 226). Os respectivos dispositivos tinham, claramente, a finalidade de regular o trabalho de operários, empreiteiros e artífices urbanos, e tiveram pouca repercussão em um país cuja atividade econômica consistia quase exclusivamente na agricultura de exportação. De qualquer modo, chama a atenção a ausência de prazos legais para os contratos de trabalho, os quais eram fixados livremente pelas partes, bem como a previsão de que os trabalhadores eram obrigados a cumprir o contrato até o fim, conquanto em caso de descumprimento não estivesse prevista pena de prisão, mas somente responsabilização por perdas e danos.

A Lei 2040, de 28.09.1871 (BRASIL, 1871), conhecida por Lei do Ventre Livre, foi certamente um impulso para a abolição da escravatura, inclusive porque instituiu algumas hipóteses de libertação imediata de escravos - por exemplo, em relação àqueles pertencentes à Coroa. Nessa lei, entretanto, percebe-se a já dramática questão do trabalho dos libertos, um problema sempre mal resolvido em nossa experiência histórica. Com efeito, a referida lei possuía o seguinte dispositivo:

\footnotetext{
Art. $6^{\circ} .[\ldots]$

$\S 5^{\circ}$ : Em geral os escravos libertados em virtude desta lei ficam durante cinco anos sob a inspeção do governo. Eles são obrigados a contratar seus serviços sob pena de serem constrangidos, se viverem vadios, a trabalhar nos estabelecimentos públicos. Cessará, porém, o constrangimento do trabalho sempre que o liberto exibir contrato de serviço (BRASIL, 1871).
}

Assim, os libertos passaram a ter a obrigação de alienar seus serviços, circunstância que, embora não fosse uma novidade no século XIX, revelava preocupação com a massa de ociosos que ocupava as cidades. Aos poucos tentou-se utilizar mecanismos para obrigar os negros libertos ao trabalho, mais como forma de se resolverem os problemas sociais decorrentes das massas de desocupados nas cidades do que propriamente de se resolver o problema da carência de mão de obra, pois, para isso, os negros eram tidos como imprestáveis e a real solução parecia residir apenas na imigração de mão de obra europeia.

A lei de locação de serviços - Decreto 2827, de 15.03.1879 - (BRASIL, 1879) foi provavelmente a mais importante política de trabalho livre do Império, embora aplicável apenas aos trabalhos da agricultura. Desde seu primeiro projeto, apresentado em 1869, revelava-se, entretanto, que o seu principal objetivo era "o uso da coerção como instrumento necessário para forçar o empregado a cumprir as exigências contratuais. Essa colocação está em linha com o objetivo dos desejos dos empregadores: mão de obra segura, dócil e estável" 
(GEBARA, 1986, p. 86). O projeto original, pensado apenas para os trabalhadores do território nacional, foi logo modificado para propiciar condições de imigração de novos colonos, pois isso constituía a principal preocupação da elite econômica da época. O texto aprovado se aplicava tanto aos trabalhadores nacionais quanto aos estrangeiros.

A lei de 1879 estava atrelada a dois objetivos simultâneos. De um lado, pretendia "tornar as condições de vida mais atrativas para o imigrante, de tal maneira que fossem oferecidas a ele alguma garantia e proteção legal" (GEBARA, 1986, p. 88); de outro, dar "uma atenção aos momentos conflituosos, à experiência das greves e rebeliões que assolaram as fazendas por toda a década de 70" (LAMOUNIER, 1988, p. 124). Aflorava o sentimento de que o País se encontrava em uma época de transição, do trabalho escravo para o trabalho livre, e foram muitas as tentativas de se buscar uma mão de obra adequada a essa transitoriedade, inclusive o frustrado experimento de imigrar trabalhadores chineses, "não como elemento de colonização, mas como "machina de trabalho"” (LAMOUNIER, 1988, p. $138)^{4}$. A tentativa de imigração de mão de obra chinesa se frustrou, em que pesem os esforços das autoridades brasileiras, apenas porque o governo chinês anteviu a possibilidade de estabelecimento de novas formas de servidão dos seus súditos.

O artigo 16 da lei de 1879 estipulava que o prazo dos contratos de locação dos libertos seria o estabelecido na Lei 2040, de 28.09.1871. Isso colocava os libertos em uma categoria intermediária, "um produto da transição e, como tal, distinto do imigrante, não podendo, portanto, ser confundido com trabalhadores livres" (GEBARA, 1986, p. 90), o que bem demonstra os preconceitos existentes a respeito da mão de obra nacional disponível. $\mathrm{O}$ liberto era um semilivre, da mesma forma que outros trabalhadores do campo, como os agregados.

A descrença secular no trabalhador nacional marcou todo o período escravista e foi utilizada ideologicamente pelas elites para se obter abundante mão de obra. $\mathrm{O}$ trabalhador livre nacional continuou a ser visto como inapto e indisciplinado para o trabalho. A degenerescência da raça, a imprestabilidade do braço nacional para o trabalho, a tendência ao alcoolismo e à imoralidade continuaram a ser a tônica da visão do trabalhador brasileiro. A

\footnotetext{
4 A proposta de imigração chinesa tinha por finalidade obter, nas palavras de um parlamentar da época, trabalhadores "sem mulheres, sem família, obedientes, servis, que aceitem uma tarefa determinada e liguem-se a ela sem resistência e sem reação" (LAMOUNIER, 1988, p. 138). As críticas a essa proposta, entretanto, não eram muito mais nobres, pois se insurgiam contra “o perigo de 'mongolização' do país; com seus salários baratos, os chineses podiam concorrer com o trabalhador nacional e, pelas condições dos contratos que firmavam, afastariam a imigração europeia" (LAMOUNIER, 1988, p. 141). Assim, a principal crítica à proposta era de que essa política obstaria o processo de branqueamento do País.
} 
preocupação com o trabalho dos libertos, entretanto, crescerá nos anos subsequentes, em razão das preocupações com as massas de negros desocupados nas cidades.

A Lei 3270, de 28.09.1885, conhecida por Lei dos Sexagenários (BRASIL, 1885), reflete essa preocupação com os libertos. Essa lei, de um lado, aumentava as hipóteses de libertação de escravos por fundos ou por iniciativa dos proprietários, mas, de outra parte, procurava manter amarras para fixar os ex-escravos aos antigos donos e para constranger os libertos ao trabalho. Demonstram bem essa política os seguintes parágrafos do artigo $3^{\circ}$ da referida lei:

$\S 4^{\circ}$ Os libertos obrigados a serviço nos termos do parágrafo anterior, serão alimentados, vestidos e tratados pelos seus ex-senhores, e gozarão de uma gratificação pecuniária por dia de serviço, que será arbitrada pelo ex-senhor com aprovação do Juiz de órfãos.

[...]

$\S 14^{\circ}$ É domicilio obrigado por tempo de cinco anos, contados da data da libertação do liberto pelo fundo de emancipação, o município onde tiver sido alforriado, exceto o das capitaes.

$\S 15^{\circ} \mathrm{O}$ que se ausentar de seu domicílio será considerado vagabundo e apreendido pela polícia para ser empregado em trabalhos públicos ou colônias agrícolas (BRASIL, 1885).

Chama a atenção o fato de, embora existisse no campo uma grande quantidade de trabalhadores livres e semilivres, agregados, lavradores em torno de grandes propriedades, desocupados urbanos e tantos outros, nenhuma regra legal lhes ser dirigida. Todas as regras criadas tinham por finalidade facilitar a imigração ou constranger o liberto ao trabalho. Tudo indica que isso ocorria porque

as dificuldades de colocação na sociedade escravocrata, em que grande parte das ocupações estava entregue aos escravos, condicionaram quase toda a camada de agregados a existir como uma camada flutuante e instável, que se mudava com frequência em busca de serviço ou da proteção dos mais diferentes tipos de família (SAMARA, 2005, p. 178).

Assim, em relação a essa população flutuante, bruta e que vivia para a mera subsistência, não havia preocupação das elites econômicas, pois os sistemas legais e extralegais já davam conta dos necessários controles, até porque estavam condicionados pela realidade socioeconômica.

Durante todo o período imperial, em razão da preocupação quase exclusiva com as consequências econômicas do trabalho, "a defesa da escravidão não era uma tarefa de que a totalidade dos parlamentares pudesse abrir mão", mas, de outra parte, esses parlamentares estavam "envolvidos numa dificílima tarefa, qual seja, defender a propriedade escrava num momento em que eles próprios não dispunham de muitos elementos para argumentar em favor de sua legitimidade" (MENDONÇA, 2001, p. 78). A abolição da escravatura em 1888 e a proclamação da República em 1889 não eliminaram a política imigracionista, mas até a Revista da Faculdade de Direito - UFPR, Curitiba, vol. 59, n. 3, p. 133-165, 2014. 
reforçaram. O Decreto 213, de 22.02.1890 (BRASIL, 1890), revogou a Lei de 13 de setembro de 1830, a de 11 de outubro de 1837 e o Decreto 2827, de 15.03.1879, e "todas as disposições exorbitantes do direito comum, relativos aos contratos de locação de serviço agrícola" (BRASIL, 1890, art. $1^{\circ}$ ), justificando-se na necessidade de se evitar o descrédito injusto da nação brasileira no estrangeiro e de atrair imigrantes e povoar o País. O referido Decreto 213 deixa claro que prevaleceria a partir de então o "direito commum" (BRASIL, 1890, art. 1"). Qual seria esse direito? O puro direito contratual, configurado em consensos puramente verbais e informais, passíveis de prudente análise caso a caso pelo Judiciário e de alguma regulação pelos Estados da Federação, ambos dominados pelas elites rurais. Como o trabalho livre na área rural estava fundado em condições de dependência ou de semidependência para com os latifúndios, com baixo nível de acesso à terra, a regulação dos contratos agrícolas estava totalmente subordinada aos interesses das oligarquias regionais, que passaram a ser o centro da normatividade durante a Primeira República.

Houve tentativas posteriores de edição de uma nova lei geral de contratos de trabalho e de locação de serviços (MENDONÇA, 2001, p. 160), mas todas fracassaram, e o século XIX findou sem que houvesse nova legislação que disciplinasse o trabalho nacionalmente, exceto as parcas regras do Código Comercial. É curioso observar que essa liberalização absoluta e tardia da mão de obra a partir de 1890 estava em contraste com o verificado no centro do capitalismo. Na Europa, a década de 1870 foi "de longe o período mais ativo da legislação social de todo o século XIX" (POLANYI, 2000, p. 254) e o protecionismo ao trabalho continuou forte nas décadas seguintes. Essa disparidade não se deve à diferença de regime ou de ideologia política, mas à diversidade de sistemas econômicos. A legislação social do final do século XIX foi promovida por governos europeus, também conservadores, apenas porque "eram exigidas para proteger o homem industrial das implicações da ficção da mercadoria em relação à força de trabalho" (POLANYI, 2000, p. 163). As contradições da sociedade industrial puderam ser resolvidas nos países europeus por meio da legislação social porque as condições macroeconômicas estavam sustentadas pelo colonialismo, de modo que havia condições de mercado externo para seus produtos industrializados e colônias fornecedoras de matéria-prima (natureza) de baixo custo. Essas contradições, obviamente, não afetavam o Brasil, cujas urgências econômicas estavam ligadas apenas à necessidade de suprir mão de obra às suas elites, porquanto um brutal sistema político já dava conta do suprimento de terras. Assim, as condições macroeconômicas, em um país fornecedor de matéria-prima para o centro do capitalismo, exigiam uma política exatamente contrária, de redução 
progressiva dos custos da mão de obra, porquanto a baixa industrialização e o sistema político autoritário não permitiam alteração na estrutura social.

A extinção das leis de locação de serviços poderia indicar uma mudança nos mecanismos de produção e uma nova visão sobre a mão de obra nacional, mas, em realidade, apenas representava uma nova estratégia de redução dos custos produtivos imposta pelas elites econômicas. O instrumento jurídico exclusivo continuou a ser o contrato, agora puramente informal e sujeito ao paternalismo local. Há que se observar que as leis revogadas tinham por finalidade fazer garantir o contrato em favor dos fazendeiros. Os novos ocupantes do poder perceberam que, em vez de leis específicas e prejudiciais à imagem externa do País, melhor seria a mera aplicação do contrato puro e simples e dos costumes. Esse contrato, entretanto, não era o contrato do Iluminismo, mas o fincado na tradição e nos sistemas de clientelismo e paternalismo com os quais a mão de obra livre foi se construindo paralelamente ao regime escravista e que se tinha por costumeiro. Faltava entre nós, portanto, a "crença na missão civilizadora do contrato" (RODRIGUES, 1975, p. 187-8) . O contrato era encarado, pela perspectiva rasteiramente utilitarista das elites políticas e econômicas, como um instrumento de regulação de obrigações econômicas, e não como de equilíbrio moral da sociedade. A moral abstrata era algo estranho ao contrato, e este compreendia o compadrio, a vizinhança e o favor.

A ideia de que não se deviam criar regras gerais a respeito do contrato de trabalho era consenso entre liberais, conservadores, evolucionistas, positivistas e quaisquer outras correntes de pensamento importadas da Europa, pois nesse aspecto prevalecia uma versão cabocla, ligada à índole da nossa gente. Miguel Lemos (1890 apud RODRIGUES, 1975, p. 187-8), por exemplo, ao pedir a revogação de uma lei municipal regulamentadora do serviço doméstico, afirmou, em nome do Apostolado do Positivismo do Brasil, que "a liberdade de profissões é um princípio fundamental do regime republicano", que "é destituída de fundamento racional, a pretensão de querer regular por lei relações que só o podem e devem ser pelas opiniões e pelos costumes", que "tais regulamentos só servem para agravar e sistematizar a opressão dos fracos pelos fortes, instituindo uma nova escravidão" e que

os abusos que se procuram sanar por este modo ilusório e despótico, só desaparecerão pelo levantamento do nível moral, tanto dos proletários como, sobretudo, dos patrões, resultado este que não pode ser obtido por meio de regulamentos ou decretos, mas pela marcha espontânea da evolução social (LEMOS, 1890 apud RODRIGUES, 1975, p. 187-8).

\footnotetext{
${ }^{5}$ Há que se ter em conta que esse "é um dos mais potentes motores do Direito contemporâneo. Mas é também de feitura estritamente ocidental" (SUPIOT, 2007, p. 99). 
O trabalho durante todo o Império, portanto, ficou marcado pelo escravismo, mas essa marca não desapareceu de imediato na Primeira República. Mesmo a titubeante industrialização brasileira do primeiro quartel do século XX não foi suficiente para afetar substancialmente a estrutura social forjada no período escravagista ${ }^{6}$, pois a maior parte da população se encontrava e prestava serviços no campo, sob a proteção das elites econômicas locais. À incipiente urbanização, por sua vez, não se seguiu uma suficiente e eficiente inserção dos trabalhadores em sistemas industriais que produzissem uma educação para o trabalho livre (contratual), de modo que o personalismo e o autoritarismo continuaram a marcar essas relações de poder, principalmente no trabalho doméstico, substitutivo das relações pessoais e escravagistas do meio rural $^{7}$.

O trabalho livre ainda foi, por muito tempo, moldado pelo viés do regime escravocrata, pois sofria influxos do sistema de trabalho até então prevalecente, razão pela qual a "dominação entre homens livres configurou-se num forte sistema autoritário, basicamente constituído por associações morais" (FRANCO, 1983, p. 217). Esse sistema autoritário, cujo poder estava tomado por elites locais, mantinha as estruturais sociais e econômicas anteriores, moldadas inconscientemente por visões de mundo que desapareceram do discurso formal, mas que insistiam nas práticas sociais. Assim, a incipiente industrialização brasileira do final do século XIX e início do século XX nasceu marcada pela tentativa de escravização dos seus trabalhadores e pela resistência deles.

O paternalismo, sistema de dominação também conectado à escravidão, assume cada vez mais relevante função de controle social. Como bem aponta Chalhoub (2001, p. 114-5):

\footnotetext{
${ }^{6} \mathrm{O}$ uso de condições escravagistas sob o capitalismo não é um traço exclusivamente brasileiro ou latinoamericano. A própria industrialização europeia foi realizada com resquícios do sistema escravagista e para comprovar isso basta a farta literatura que existe sobre exploração do trabalho de homens, mulheres e, principalmente, crianças. Marx, com razão, depois de apontar as crueldades contra as crianças nas fábricas inglesas e a apologia ao tráfico negreiro na Inglaterra, concluiu que "a escravidão dissimulada dos assalariados na Europa precisava fundamentar-se na escravatura, sem rebuços, no Novo Mundo" (MARX, 2006, v. II, p. 873). Isso torna evidente que por meio do contrato também é possível algum tipo de escravidão. De outra parte, o perspicaz comentário comprova que os aspectos morais nunca deixam de acompanhar a dominação econômica, pois a normalização das expectativas é imprescindível para a formação do capital simbólico.

${ }^{7}$ Não se deve subestimar o peso da transferência de riqueza operada por meio desse sistema de redução de custos, que persiste na estrutura dos países periféricos. A respeito da realidade observada de 1980 a 1990 , Susan George (1997, p. 16) afirma que "no Sul as elites tiveram muitas possibilidades de enriquecer-se por meio dos ajustamentos estruturais; os salários são baixos, os domésticos não custam nada, os serviços públicos não existem mais e no seu lugar existem os privados, mas para as elites não mudou nada porque possuem escolas privadas, hospitais privados, tudo privado". Essa realidade já se observava no País desde suas origens, com a diferença que, antes de 1930, todos os serviços públicos eram de posse dessa elite. O problema é que essa realidade persiste até hoje e pode ser constatada na resistência constante não apenas à proteção legal do trabalho doméstico, mas até mesmo à sua contratualização. O trabalho doméstico é ainda refém das relações costumeiras. 
A imagem da relação patrão-empregado geralmente veiculada pelas classes dominantes brasileiras na República Velha era de que esta relação se assemelhava em muitos aspectos à relação entre pais e filhos. O patrão era uma espécie de 'juiz doméstico' que procurava guiar e aconselhar o trabalhador, que, em troca, devia realizar suas tarefas com dedicação e respeitar seu patrão.

A própria palavra patrão, que vem de patronus, antigo senhor de um liberto, dá bem a ideia do modo como os trabalhadores livres eram vistos. Até meados da Primeira República ainda se impunha a dicotomia entre o trabalho do brasileiro e o trabalho do europeu, este imaginado como mais eficaz e civilizado. O branqueamento almejado não era simplesmente étnico, mas também simbólico e econômico. A verdadeira abolição desejada foi a de o senhor libertar-se do escravo, mais que o contrário. Esse desejo de europeização, entretanto, torna-se cada vez mais contraditório conforme avança o novo modelo social, urbano e industrial, que se distancia aos poucos das estruturas rurais do País.

Assim, um novo aspecto ideológico relevante aparece. Durante o século XIX, em relação ao trabalhador nacional, a

\footnotetext{
cantada e decantada inaptidão para o trabalho foi sempre um fator material e ideologicamente reiterado pelos potentados da cafeicultura paulista, a fim de, inicialmente, reproduzir a escravidão, e depois criar oferta abundante de braços por meios de renovados e volumosos fluxos de estrangeiros injectados do exterior (KOWARICK, 1994, p. 103)
}

De modo desigual nas diversas regiões do País, o trabalhador nacional passa aos poucos a ingressar no trabalho do campo e da cidade, principalmente a partir do início do século $\mathrm{XX}$, quando os fluxos imigratórios começam a diminuir e os migratórios, principalmente em razão das secas no Nordeste, a aumentar. A migração, em que pese toda a precariedade que a acompanha e o esvaziamento cultural que a segue, rompe com uma parte da dominação local sobre os trabalhadores livres, os quais são inseridos em novos contextos de exploração do trabalho. Aos poucos "o nacional foi incorporado às tarefas produtivas nas quais não acorreram imigrantes: lá trabalhou e, como por encanto, de um momento para o outro, deixou de ser 'vadio"” (KOWARICK, 1994, p. 106).

O Código Civil instituído pela Lei 3071, de $1^{\circ}$ de janeiro de 1916 (BRASIL, 1916), estabeleceu várias regras a respeito da locação de serviços, nos artigos 1216 a 1236, e da empreitada, nos artigos 1237 a 1247. Embora tenham sido introduzidas melhorias, como a estipulação do prazo máximo de quatro anos para os contratos (BRASIL, 1916, art. 1220), seu impacto na realidade social foi diminuto, porque o imaginário do contrato estava distante das relações pessoais prevalecentes. Essas novas regras incluíam o trabalho agrícola e estabeleciam critérios para a resilição dos contratos por justa causa e as respectivas perdas e 
danos, mas já nasceram com baixa densidade normativa por não estarem adequadas à estrutura socioeconômica da época, de modo que nunca alcançaram valor simbólico significativo, inclusive porque uma nova legislação do trabalho começou a ser editada, ainda que de forma esparsa, na década de 1910.

\section{POLÍTICAS PÚBLICAS DE INDUSTRIALIZAÇÃO E DE LEGISLAÇÃo SOCIAL - PERÍODO DE 1930 A 1980}

A partir dos meados do século XIX a consciência política do atraso e a ânsia por progresso se tornavam cada vez mais presentes, mas, de forma contraditória, as estruturas sociais e econômicas impunham o predomínio da posse e o personalismo como meio de dominação. Aos poucos, essa concepção de um país estruturado quase que exclusivamente em grandes fazendas de exportação vai se tornando incompatível com as alterações verificadas no capitalismo central, sedento por novos mercados de consumidores. Ao mesmo tempo, ficava cada vez mais evidente que a organização econômica baseada apenas na exportação de produtos primários não só era prejudicial à maior parte da população, mas até mesmo colocava em perigo os interesses de parte das elites rurais. De outra parte, as alterações produzidas na Europa questionavam cada vez mais o suposto absenteísmo estatal ${ }^{8}$ na regulação econômica e social, aparecendo entre nós a questão social. É contra os restos carcomidos da ordem social criada por esse contraditório absenteísmo estatal que se levanta o movimento iniciado em 1930, conhecido, paradoxalmente, por Revolução Liberal.

O capitalismo industrial há muito era uma realidade na Europa e nos Estados Unidos. A fase inicial desse capitalismo industrial havia sido marcada por um contínuo desenvolvimento das capacidades de produção, mas o acirramento da concorrência e a diminuição dos lucros conduziram a sucessivas crises, como a Grande Depressão (18731895). O capitalismo industrial baseava-se primordialmente no elemento produção, o que importava em sucessivos e curtos períodos de progresso e de recessão. Foi nessa sucessão de crises que surgiu outro produto da modernidade - o desemprego, bem como a reação socialista e a afirmação das classes operárias. Também surgiram os cartéis e os trustes como meio de controlar crises de produção e de concorrência, o que deu origem aos monopólios, frutos da concentração da produção e do sistema financeiro.

\footnotetext{
${ }^{8} \mathrm{O}$ absenteísmo estatal antes de 1930 só pode ser considerado ideologicamente suposto, mas não totalmente real. Sempre que foi necessária para preservar os interesses dos fazendeiros houve intervenção do governo, tanto em políticas de redução de custos como no manejo da moeda.
} 
Todos esses aspectos do capitalismo do final do século XIX e início do século XX se associaram a várias crises de demanda e conduziram, progressivamente, a políticas intervencionistas estatais, por meio da proteção social e de interferência na moeda (criação de bancos centrais), o que não se realizou sem muitas resistências dos liberais. $O$ intervencionismo no contrato, na Europa, passa a ser, cada vez mais, uma medida aceita como reação pragmática que busca eliminar os problemas ocasionados pelo liberalismo econômico e sua utopia de um mercado auto-regulável ${ }^{9}$.

Em todo o mundo o Estado precisou intervir progressivamente. Primeiramente, no mercado de trabalho e da terra, por meio da proteção social. Depois, por meio de intervenção na moeda. A Primeira Grande Guerra de 1914-1918 modificou muitas estruturas políticas e, de outra parte, o desenvolvimento da produção em massa conduziu a uma nova e sensível crise de demanda, da qual a Crise de 1929 foi apenas um dos reflexos. O New Deal americano e a instituição de políticas de desenvolvimento do regime de demanda, principalmente com base nas ideias de Keynes, foram os fundamentos econômicos que progressivamente conduziram ao denominado Estado de Bem-Estar Social, regime dos países desenvolvidos no pós-guerra, mas que só tardiamente e de modo incompleto se apresentou ao Brasil.

O Brasil não poderia passar imune a essas alterações no capitalismo central, e a crise mundial acarretou a perda de poder por parte das oligarquias locais, principalmente as ligadas à agricultura de exportação. Sobem ao poder oligarquias locais dissidentes, chefiadas por Getúlio Vargas, cuja origem política estava diretamente vinculada ao castilhismo gaúcho, vinculado, por sua vez, ao "ideal comtiano da passagem da fase militar-feudal para a fase industrial da Humanidade" (BOSI, 1992, p. 284). Assim, um dos fundamentos ideológicos desse movimento era a industrialização do País. “Quando, em 1930, os líderes republicanos do Sul conquistaram o poder federal na esteira de um movimento nacional liderado por Getúlio Vargas, os mesmos ideais de industrialização e controle central encontraram maior espaço para se concretizarem" (BOSI, 1992, p. 388). A visão positivista, motora desses ideais, foi também decisiva para o arcabouço jurídico montado, como bem demonstrou Bosi (1992, p. 294):

Muito do que se afirma sobre a influência dos modelos corporativos na legislação trabalhista do Estado Novo se esclarece melhor pelo estudo das medidas tuteladoras

\footnotetext{
9 “A grande variedade de formas nas quais surgiu o contramovimento 'coletivista' não foi devida a qualquer preferência pelo socialismo ou pelo nacionalismo por parte dos interesses envolvidos, mas deveu-se exclusivamente ao alcance mais amplo dos interesses sociais vitais afetados pela expansão do mecanismo de mercado" (POLANYI, 2000, p. 177).
} 
que já figuravam no ideário do Apostolado Positivista, na versão que lhes deu Júlio de Castilhos e nas intervenções pontuais de Borges de Medeiros.

A propulsão política do movimento de 1930 estava na denominada "questão social". Como destaca Vianna (1996):

Em sua nova configuração, a revolução passiva terá como "fermento revolucionário" a questão social, a incorporação das massas urbanas ao mundo dos direitos e a modernização econômica como estratégia de criar novas oportunidades de vida para a grande maioria ainda retida, e sob relações de dependência pessoal, nos latifúndios.

Esse "fermento", contudo, tinha que lutar contra a massa dura dos demais ingredientes da receita, ou seja, contra a massa social e cultural do País, bem como contra a resistência de significativa parte das oligarquias rurais, insatisfeitas com a perda de seu poder. Acima de tudo, era necessário criar o Estado, esse ente abstrato e desconhecido da maioria da população, submetido que estava à posse (fruição) de uma diminuta elite ${ }^{10}$. É a partir dessa configuração que a legislação trabalhista brasileira começa a ser elaborada em 1931, sempre preocupada com industrialização do País, concebida agora como o modo adequado para deixá-lo mais próximo da civilização.

Oliveira Vianna, um dos mais importantes ideólogos dessa nova ordem jurídica, reconhece tudo isso claramente ao afirmar que

o que temos até agora tentado resolver, com as nossas leis sociais, são as questões do trabalho na indústria e no comércio, isto é, do trabalho das populações que vivem dentro das nossas capitais e cidades, que são os centros do nosso capitalismo nascente e onde a grande indústria começa a levantar as suas poderosas estruturas (VIANNA, 1951, p. 16-7).

Esse autor reconhecia que o "mundo rural brasileiro continua intacto, fora da ação tutelar e renovadora desta nova política social" (VIANNA, 1951, p. 16 et seq.) e, ao mesmo tempo, não escondeu que as alterações produzidas no mundo do trabalho estavam conectadas com a Europa e com um desejo de civilização, ao afirmar que o Brasil não é

nenhuma tribo de indígenas arborícolas, [...] fora de todo contacto com os povos civilizados. Vivemos entre eles, respirando o seu clima moral, sentindo as suas preocupações e aspirações; consequentemente, não nos podemos subtrair à influência das correntes espirituais que os agitam (VIANNA, 1951, p. 12).

As reformas sociais produzidas a partir de 1930 sempre estiveram muito mais vinculadas a um projeto de industrialização do País do que a um projeto de emancipação

${ }^{10}$ Tem razão Adalberto Paranhos (1999, p. 37) ao afirmar que "a ideologia do trabalhismo constitui uma 'região ideológica' da ideologia do Estado". Para isso “o Estado se transfigura em obra de arte” (Ibid, p. 67), cujo padrão estético é orientado pelo artista da política para a criação de uma obra bem específica: o Estado-Ordem.

Revista da Faculdade de Direito - UFPR, Curitiba, vol. 59, n. 3, p. 133-165, 2014. 
social (i. e., a uma sociedade de cidadãos com direitos econômicos e sociais mais amplos), o que pode ser observado pelo fato de a maior parte dos trabalhadores ter ficado à sua margem. Não é por outro motivo que os trabalhadores domésticos só passaram a ter alguma proteção jurídica mais consistente a partir da Lei 5859, de 11.12.1972 (BRASIL, 1972), e os trabalhadores rurais a partir da Lei 5889, de 08.06.1973 (BRASIL, 1973). A Consolidação das Leis do Trabalho (CLT) (BRASIL, 1943), principalmente em razão das limitações contidas no seu artigo $7^{\circ}$, era um regime legal destinado à proteção de uma minoria dos trabalhadores da indústria e do comércio urbano.

A crítica central a essa legislação trabalhista da década de 1930 diz respeito à sua fonte autoritária, à ideia de que foi algo outorgado, uma concessão e um favor ditatorial. Outra crítica contundente é de que a legislação trabalhista foi moldada pelo paternalismo, com formalismo e artificialidade. Argumenta-se que, por esse motivo, a partir de 1930, em razão da artificialidade do sistema, o movimento sindical teria perdido sua espontaneidade e autenticidade. Outras críticas que se agregam são as relacionadas ao corporativismo do sistema legal, ao descumprimento sistemático das regras (insinceridade legal) e à ausência de mecanismos para resolução de queixas no local de trabalho, como delegados sindicais ou sistemas de arbitragem. Esse é um debate que ainda permeia a análise da legislação trabalhista. A força dos seus argumentos reside principalmente na imagem quase automática que o ciclo histórico traz à mente: autoritarismo e oligarquia. Assim, toda a legislação trabalhista seria apenas um mecanismo que a classe dominante instituiu para continuar a sujeitar a classe trabalhadora.

Há que se ponderar, entretanto, que existe uma diferença substancial entre sujeitar-se à pessoa e sujeitar-se à lei, pois neste caso o objeto da sujeição torna-se apropriável, o que torna contraditório o mecanismo de dominação, que passa a propiciar liberdade. Há vários aspectos morais, simbólicos e econômicos que demonstram que a legislação trabalhista foi justamente um dos guindastes que rompeu com a ordem precedente, ainda que esse rompimento tenha sido muito lento e só consolidado com a Constituição de 1988.

Existem outros argumentos contrários à tese de que a legislação trabalhista tenha sido puramente autoritária e artificial. O primeiro e mais importante é que essas regras, configuradas a partir de 1943 na CLT, foram responsáveis pela criação de uma subjetividade trabalhista, uma consciência legal dos trabalhadores. Com efeito,

... a legislação social e trabalhista outorgada pelo governo aos operários de maneira tão benevolente transformou-se, a seguir, num direito legal; e quando um operário exige que ela seja cumprida, a relação original de "outorga" (ou seja, de dependência) desaparece. O que passa a contar é que o cidadão está exigindo o Revista da Faculdade de Direito - UFPR, Curitiba, vol. 59, n. 3, p. 133-165, 2014. 
cumprimento da lei, que ele exige "seus direitos" como homem livre (FRENCH, 2001, p. 64).

Como bem destacou Gomes (1994, p. 9), "Quando se cria um mercado de trabalho livre no país é necessário também criar um modelo de trabalhador, e o referencial da escravidão se impõe para a construção de qualquer tipo de discurso que envolva uma ética do trabalho". Por isso, a nova subjetividade acabou por ser a primeira tentativa real de superação do referencial da escravidão. Sincera ou não, ela conseguiu gerar esse efeito, ainda que muito mais no campo simbólico.

De outra parte, a adesão da classe trabalhadora à legislação reflete o cálculo pragmático dos mais fracos e a instituição de uma filosofia dos direitos. "Para qualquer grupo social, é sempre melhor se você pode ter a lei e o poder a seu lado. Se você só puder ter um dos dois, o poder é evidentemente preferível à lei. Se você não tem o poder, entretanto, não se discute que a lei é ainda inquestionavelmente melhor do que nada" (FRENCH, 2001, p. 67). A lei trabalhista introduz no universo dos trabalhadores, provavelmente pela primeira vez, a ideia da igualdade homogeneizadora, a cultura de direitos universais, que só pode ser introjetada como prática pré-reflexiva por estruturas normativas.

Além disso, e em qualquer hipótese, a construção simbólica da classe trabalhadora exige a crença no Direito e na Justiça como estratégia de mudança social. A perspectiva de vida das pessoas é definida tanto por intuições morais quanto por necessidades materiais, e a modificação das estruturas pré-modernas exigia o argumento moral. "Só é possível me convencer mudando minha leitura de minha experiência moral e, em particular, minha leitura histórica de vida, das transições por que passei - ou talvez recusei-me a passar" (TAYLOR, 2005, p. 102). A lei passa a assumir um claro papel de moral universalizante, ao mesmo tempo em que, finalmente, o trabalho passa a ser erigido a valor fundamental da sociedade. A luta social apenas muda de lugar, pois a adesão à lei é sempre uma estratégia de luta dos mais fracos.

A legislação trabalhista, em realidade, é uma apropriação da fala da classe trabalhadora, com propósitos políticos e econômicos, e essa apropriação é de ordem moral, o que significa dizer que altera a base discursiva tanto da classe dominante quanto da dominada. Há, de fato, uma intenção de apagar a memória da palavra do trabalhador. Sucede que esse apagamento só pode realizar-se pela releitura e integração em outro contexto do próprio discurso operário. Ao fazer isso, ainda que a maioria dos elaboradores da CLT tivesse um perfil conservador e elitista, a orientação moral ingerida acaba por ser transformadora. 
Essas alterações culturais e jurídicas foram facilitadas pela acentuada modificação que houve nas condições da mão de obra do País a partir da década de 1920. Os fluxos migratórios internos, principalmente dos atingidos pela seca no Nordeste, passam a ser fonte de suprimento de mão de obra barata e farta para as regiões Sudeste e Sul. A inserção do trabalhador nacional nos meios produtivos se torna mais fácil de um lado, e indispensável de outro, pois a imigração se torna rarefeita. Essa transformação geoeconômica é seguida de paulatina mudança da visão predominante sobre o trabalho do brasileiro, processo que tivera início ainda na Primeira República e que ainda prossegue. Houve o retorno do mito do bandeirante, o andarilho converte-se em heroico colono. $\mathrm{O}$ seringueiro, o sertanejo, o jangadeiro, são alçados a indicativos da tenacidade e da força do trabalhador brasileiro por trás de sua aparente fragilidade. Passa a ser destacada em nosso imaginário a índole pacífica do nosso povo, que trabalha bravamente e sem reclamar. A miscigenação passa a ser um valor positivo do brasileiro, síntese inigualável de três raças. Há uma nítida preocupação de modificar a baixa estima do brasileiro como um todo, e do trabalhador em especial ${ }^{11}$.

Todas essas transformações culturais, econômicas e sociais estavam ligadas a uma política nacional desenvolvimentista, que começa com o movimento de 1930 e se estende aproximadamente até 1980-1990. Trata-se, certamente, da mais vigorosa fase de políticas públicas relativas ao trabalho livre no Brasil. O Estado intervém nas relações sociais com o objetivo de criar condições de industrialização e de instituir um efetivo mercado de trabalho urbano e industrial e, com isso, pretende e obtém uma participação inusitada da sociedade civil, inclusive por meio dos sindicatos. O desenvolvimento industrial se introduz no imaginário de todos os grupos sociais e políticos como valor máximo da Nação, à esquerda e à direita, de modo que nem o Golpe Militar de 1964 barra o respectivo processo, embora tenham ocorrido retrocessos para os trabalhadores, como o fim da estabilidade decenal, com a criação do Fundo de Garantia do Tempo de Serviço - FGTS, pela Lei 5107, de 13 de setembro de 1966 (BRASIL, 1966).

Esse período é caracterizado por forte migração regional, por urbanização rápida e desorganizada, por favelização das cidades, pela heterogeneidade das formas de trabalho, pela industrialização diversificada como base do crescimento, pela regulação legal do trabalho, pelo precário acesso à terra por parte dos trabalhadores, por atividades informais de trabalho e por outras atividades de baixa renda para considerável parte da população urbana. Surge um

${ }^{11}$ Oliveira Vianna (1951, p. 36-7) esclarece que a baixa estima dos trabalhadores era, ainda no início do século $\mathrm{XX}$, um problema mundial, pois mesmo na Europa havia esforços "no sentido de conseguir libertá-los da convicção [...] de que não passam de pobres diabos". 
mercado de trabalho polimorfo e contraditório, marcado, por um lado, por abundante mão de obra com baixa qualificação técnica e sujeita a baixos salários, e de outro, por uma estrutura regulada em moldes capitalistas, com empregos estáveis, de maior qualificação e com melhores salários ${ }^{12}$. Esse período também é marcado por outra contradição: embora houvesse precariedade de considerável parte das condições de trabalho, o desemprego estrutural era algo que não se impunha nas análises econômicas e no imaginário social ${ }^{13}$. "Entre as décadas de 1930 e 1970, o problema do desemprego foi relativamente pequeno ante as altas taxas de crescimento econômico que elevaram rapidamente o nível de emprego no Brasil" (POCHMANN, 2008, p. 33). Isso se altera na década de 1980, em razão da recessão e das alterações estruturais, com o aumento da densidade demográfica nas cidades em geral e no sul do País em particular.

Um dos aspectos mais importantes da intervenção estatal dessa época reside no impulso à formação profissional por meio, principalmente, do Serviço Nacional de Aprendizagem Industrial (Senai) e do Serviço Nacional de Aprendizagem Comercial (Senac). Se o objetivo era criar uma classe trabalhadora adaptada ao comércio e à indústria, era necessário formá-la. O Senai foi criado pelo Decreto-Lei 4048, de 22.01.1942 (BRASIL, 1942), e o Senac pelo Decreto-Lei 8621, de 10.01.1946 (BRASIL, 1946), custeados por meio de contribuições compulsórias feitas pelos estabelecimentos industriais e comerciais. Embora não tivessem força para interferir em parcela significativa da população, esses entes autônomos desempenharam importante papel na formação de trabalhadores para aqueles ramos da economia.

\section{POLÍTICAS NEOLIBERAIS E ASSISTENCIALISTAS - PERÍODO A PARTIR DE 1980}

Com avanços e retrocessos, o Brasil continuou o seu projeto de industrialização do modo como pôde, e, para isso, contou com a legislação trabalhista estabelecida na Era Vargas, por meio da qual se tentou algum equilíbrio nas relações entre capital e trabalho. Houve,

\footnotetext{
${ }^{12}$ A esse respeito cf. SILVA, 2008, p.10.

${ }^{13}$ A precariedade e a informalidade são marcos constitutivos do trabalho na sociedade brasileira desde a Colônia e, por constituírem a normalidade no sistema de trabalho urbano, não produziram impacto significativo no imaginário social nem foram objeto de análise econômica. O desemprego, entretanto, passaria gradativamente, a partir de 1930, a constituir um novo espectro, pois só surgiu como entidade concreta e relevante no País quando excedentes de mão de obra urbana passaram a constituir uma necessidade do incipiente mercado de trabalho fabril, em virtude da necessidade de se regularem os níveis salariais ao menor patamar possível.
}

Revista da Faculdade de Direito - UFPR, Curitiba, vol. 59, n. 3, p. 133-165, 2014. 
entretanto, novas alterações estruturais do capitalismo, a partir da década de 1970, que colocaram em dificuldades as políticas públicas até então adotadas.

Duas alterações se destacaram. Primeiramente, a crise de lucratividade verificada entre as multinacionais americanas e europeias e o acirramento da concorrência em algumas áreas específicas, como a automobilística, que impulsionou uma nova concorrência por mercados e a busca por aumento de produtividade, principalmente com a emergência de novos países produtores, como o Japão. A segunda alteração refere-se à expansão do capital financeiro sobre países periféricos, em busca de maior lucratividade, em virtude, principalmente, da existência de excedentes de capitais em bancos privados americanos e europeus, o que se acentuou com o aumento dos preços do petróleo. Inicia-se, assim, um processo nunca antes visto de mundialização do capital financeiro e das trocas comerciais. Tudo isso conduziu a

$$
\begin{aligned}
& \text { um processo de reorganização do capital e de seu sistema ideológico e político de } \\
& \text { dominação, cujos contornos mais evidentes foram o advento do neoliberalismo, com } \\
& \text { a privatização do Estado, a desregulamentação dos direitos do trabalho e a } \\
& \text { desmontagem do setor produtivo estatal (ANTUNES, 1999, p. 31), }
\end{aligned}
$$

como resposta a mais uma crise estrutural do próprio capitalismo. Essa crise decorreu do esgotamento dos meios tayloristas de produção e das dificuldades do Estado de Bem-Estar Social no centro do capitalismo.

Essas alterações não foram espontâneas, mas resultaram de escolhas políticas conscientes e produziram, entre outras inúmeras e complexas modificações nas sociedades contemporâneas, uma mudança na composição da denominada classe trabalhadora ou classeque-vive-do-trabalho ${ }^{14}$. Os trabalhadores produtivos, em atividades diretas e manuais na indústria, e que geram mais-valia diretamente no sistema, passaram a não mais preponderar em termos quantitativos, pois "o capital emprega a força de trabalho sob as formas mais variadas em cada momento histórico. Não há rigidez na forma. A única exigência é que seja funcional à lei do valor" (ALVES, 2006, p. 435). Cresce de modo acentuado o trabalho improdutivo (comércio e serviços), o qual cria "valor de uso" e não "valor de troca" (ANTUNES, 1999, p. 102). Esse crescimento tem sido acompanhado de um aumento impressionante daquilo que se tem denominado trabalho informal, efeito colateral (e inevitável) do sistema de acumulação flexível.

\footnotetext{
${ }^{14}$ Como prefere ANTUNES (1999, p. 101), para "conferir validade contemporânea ao conceito marxiano de classe trabalhadora", ao se referir a todos que vivem diretamente do trabalho próprio em benefício de outrem.

Revista da Faculdade de Direito - UFPR, Curitiba, vol. 59, n. 3, p. 133-165, 2014.
} 
Houve aos poucos uma profunda alteração dos meios de produção e de acumulação, o que gerou novos processos de trabalho (neofordismo, neotaylorismo e toyotismo) a conviverem com os processos produtivos tradicionais (fordismo e taylorismo) e até com processos antiquados e que se imaginavam superados (escravidão). Em decorrência, verificou-se, de um lado, a redução do proletariado industrial e manual nos países de capitalismo avançado e, paralelamente, uma "subproletarização" do trabalho (trabalho precário ou parcial), principalmente na periferia (ANTUNES, 1999, p. 211-2). O Brasil constitui uma evidência exemplar dessa convivência pacífica de processos de trabalho muito distintos entre si, pois incorpora modos de produção avançados (v.g. toyotismo) com uma industrialização pré-taylorista e modos de exploração do trabalho que parecem mais próximos da fase pré-industrial, como o trabalho escravo, inseridos direta ou indiretamente no sistema produtivo.

Um amplo conjunto de mecanismos de gestão passa a ser utilizado, atitude gerencial que genericamente tem sido denominada de toyotismo. O toyotismo é formado por uma

nova lógica de produção de mercadorias, novos princípios de administração da produção capitalista, de gestão da força de trabalho, cujo valor universal é constituir uma nova hegemonia do capital na produção, por meio da captura da subjetividade operária pela lógica do capital (ALVES, 2000, p. 31).

Os mecanismos de aumento da produtividade exigem, por princípio, a precarização do trabalho em algumas áreas do sistema, principalmente na periferia. A precarização da mão de obra não é um fenômeno brasileiro, mas mundial ${ }^{15}$; contudo, encontrou neste País condições inigualáveis para sua reprodução, pois as estruturas sociais de base já eram, historicamente, precarizadas, e a moral do trabalho livre ainda não tinha sido integralmente implantada. Em vários pontos o mundo atual do trabalho parece retornar ao mundo do trabalho livre da República Velha. Esse retorno também se verifica na política pós-industrial adotada, com o retorno da prevalência da exportação de produtos primários. Márcio Pochmann (2008, p. 23) explica bem isso, ao afirmar que, considerado o período de 19802005:

É cada vez maior a especialização da economia nacional em termos da produção e exportação de bens primários com baixo valor agregado e reduzido conteúdo

15 O sistema toyotista japonês, para obter a cooperação dos trabalhadores, precisa do emprego vitalício, mas "para poder garantir a seus assalariados o emprego permanente, as grandes firmas japonesas subcontratam com uma rede vasta de empresas periféricas as fabricações e prestações de serviço que a firma matriz não tem interesse vital em assumir" (GORZ, 2007, p. 69). Assim, a matriz toyotista de administração, tornada um modelo para muitas outras empresas, importa necessariamente em terceirização e precarização da mão de obra desses terceirizados. 
tecnológico, geralmente intensivo em postos de trabalho mais simples (produtos agrícolas e extrativismo mineral). Nos países desenvolvidos, verifica-se, em contrapartida, a diversificação da produção, com maior valor agregado e elevado conteúdo tecnológico na produção de bens e serviços.

Em síntese, o Brasil registra uma certa volta ao modelo de inserção internacional praticado no século 19, quando se destacou como uma das principais economias de bens agrícolas, como café, borracha, algodão, pimenta do reino, entre outras (sic).

Embora a reestruturação produtiva tenha afetado todo o mundo capitalista, o certo é que no Brasil seus reflexos sobre o mundo do trabalho foram ainda mais nocivos. $\mathrm{O}$ aumento da produtividade e da lucratividade nas áreas centrais do sistema só poderia se realizar com o aumento da precarização das franjas, pois os trabalhos menos produtivos ou com menos condições de gerar lucros são terceirizados, transferidos para a periferia. ${ }^{16}$ Por isso, mesmo entre os trabalhadores formais (com carteira assinada) cresce o trabalho precarizado, aumentando o subproletariado (subcontratados, trabalhadores part-time e terceirizados), e entre os autônomos legalizados há categorias das mais heterogêneas, desde representantes comerciais com um grande nível de dependência até pessoas jurídicas prestadoras de serviços por meio de uma única pessoa física. Essa tendência de precarização tem sido associada ao setor de prestação de serviços, como se esse setor não tivesse ligação com o sistema produtivo e como se fosse algo à parte do sistema de produção de bens. Fazem parte dessas alterações, entretanto, uma "imbricação crescente entre mundo produtivo e setor de serviços, bem como a crescente subordinação desse último ao primeiro", e daí que "o assalariamento dos trabalhadores do setor de serviços aproxima-se cada vez mais da lógica e da racionalidade do mundo produtivo, gerando uma interpenetração recíproca entre eles" (ANTUNES, 1999, p. 111. Grifos do autor).

Para dar conta da necessidade de aumentar a produtividade, e por meio das novas técnicas gerenciais, o trabalhador é introjetado no próprio mecanismo de controle, principalmente por meio da apropriação da ideia do valor subjetivo do trabalho ${ }^{17}$. O que se verifica é uma pulverização de comandos, parte deles internalizada no trabalhador que executa e ao mesmo tempo supervisiona a tarefa; outra parte é transferida para o próprio

\footnotetext{
16 "A terceirização é um componente central do espírito do toyotismo, capaz de instaurar uma 'fragmentação sistêmica' do circuito de valorização, o suporte material do 'trabalhador coletivo'. Articula-se com o just-intime/kanban, utilizando-se das vantagens comparativas postas pelas novas tecnologias microeletrônicas na produção" (ALVES, 2000, p. 203).

17 "A exaltação do trabalho, no seu ápice, enaltece todo e qualquer trabalho como único modo de dignificação do sujeito, que se constitui desde a função que desempenha e na imagem de quem o explora" (COUTINHO, 1999, p. 16). Esse revigoramento do princípio mais elementar do liberalismo lockeano acarreta o aprisionamento do sujeito, pois passa a prevalecer a ideia de que "O sujeito é o que faz, o que trabalha e para quem trabalha; em reverso, o sujeito não é, é um não-sujeito, se nada faz, se não trabalha, se não é tomado pelo capital. $\mathrm{O}$ aniquilamento do sujeito se projeta no sonho de ser explorado, para não ser tomado na pequenez e na inutilidade de quem nem para ser explorado conta" (Ibid., p. 17).
} 
cliente, que faz o controle de qualidade, ou é atribuída a terceiros. Isso não só aumenta a produtividade, mas, acima de tudo, modifica os mecanismos de coerção.

A análise histórica acima empreendida parece indicar que a fragmentação do trabalho verificada a partir de 1980 não é um problema novo. É um problema recém-descoberto ou, talvez seja mais correto afirmar, reconstruído. A precarização é um produto de um autoritarismo estrutural, que vai da economia à política, passando pela estrutura burocrática estatal. Por essa reconstrução são reorientados os mecanismos que, no País, mantêm e sempre mantiveram invisível, para o Direito, significativa parcela de sua população ${ }^{18}$.

Tudo isso conduz a um progressivo aumento da fragmentação do mundo do trabalho, à perda de relevância teórica e prática da distinção de trabalho produtivo e trabalho improdutivo, à feminização do trabalho como mecanismo de redução salarial e à perda de solidariedade do trabalho. A cidadania salarial perde espaço para a cidadania do consumo. Cidadão não é mais quem trabalha, mas quem tem condições de consumir. Essa nova morfologia social impõe a existência de uma crescente massa de excluídos, sem condições materiais ou imateriais de vender sua força de trabalho, contra alguns privilegiados, que conseguem alienar seu trabalho em condições cada vez mais instáveis.

O conhecimento transformou-se em mercadoria e, aos poucos, tornou-se uma mercadoria muito valiosa. Ser possuidor dessa mercadoria, entretanto, não torna o indivíduo mais poderoso, pois a maior especialização do trabalho acarreta também o aumento progressivo de suas necessidades, o que torna manipulável a respectiva troca. Assim, o conhecimento não traz liberdade, mas aprisionamento ao consumo.

$\mathrm{O}$ aspecto mais visível dessas alterações foi o aparecimento do desemprego estrutural. Embora grande parte do discurso político tenha se dirigido ao problema do desemprego, a realidade é que a crença na força do mercado como regulador continuou a ser a principal atitude dos governantes, e pouco se fez para aliviar o seu impacto sobre os trabalhadores. A partir de 1980 não foram realizadas alterações legislativas significativas.

O seguro-desemprego, introduzido pelo Decreto-Lei 2283, de 27.02.1986 (BRASIL, 1986a), posteriormente modificado pelo Decreto-Lei 2284, de 10.03.1986 (BRASIL, 1986b), e depois sensivelmente alterado e aperfeiçoado com a promulgação da Lei 7998, de 11.01.1990 (BRASIL, 1990b), foi a única política pública relevante sobre o tema. Como

\footnotetext{
${ }^{18}$ A invisibilidade desses seres não é apenas para o Direito. "O que existe aqui são acordos e consensos sociais mudos e subliminares, mas, por isso mesmo, tanto mais eficazes que articulam, como que por meio de fios invisíveis, solidariedades e preconceitos profundos e invisíveis" (SOUZA, 2003, p. 175). 
destaca Márcio Pochmann (2001, p. 124), ao contrário de experiências de políticas públicas verificadas em outros países,

[...] o desemprego no Brasil segue tratado como um problema menor, na maioria das vezes identificado pelas autoridades governamentais como de ordem individual, mais privado do que público. Parece ser necessário lembrar que o desemprego constitui uma das mais difíceis situações sociais e que a inexistência de atendimento social adequado ao desempregado reflete não apenas o estágio de atraso, conservadorismo e individualismo de uma sociedade, mas também o fato de o desempregado conduzir-se mais facilmente ao desespero social, à violência, às drogas, enfim, ao quadro de desamparo e de regressão numa sociedade que já tem muito desgastado o tecido social.

Não há em nosso País uma autêntica política nacional de trabalho, que estabeleça serviços públicos para o desempregado. Os problemas do desemprego são vistos como problemas de mera qualificação individual do trabalhador, como se esse estado dependesse apenas de sua condição pessoal, e não de políticas próprias que envolvam sua reinserção, a criação de mais postos de trabalho por meio de novos sistemas redistributivos, como a diminuição da jornada de trabalho e, principalmente, a criação de mecanismos de inserção pública de trabalhos tidos como socialmente irrelevantes e que proliferam como supostamente autônomos, como os dos catadores de lixo. A visão predominante é de que o crescimento econômico gerará mais empregos, embora todas as evidências indiquem que tal crescimento seja incapaz de gerar o necessário em termos quantitativos e qualitativos. O retorno da crença de que o egoísmo privado seja a fonte da virtude pública conduz à impossibilidade de se solucionarem os problemas mais graves da sociedade contemporânea, tanto os do trabalho como os socioambientais.

Por este caminho, em que as prioridades privadas prevalecem sobre as sociais, avançam o desemprego das capacidades humanas para reverter o desequilíbrio ecológico, o estado de calamidade pública, a fome coletiva, a violência e a incerteza de sobrevivência, em um mundo cada vez mais fora de controle (CARRIQUIRY, 1998, p. 246).

$\mathrm{O}$ acesso à terra continua a ser um problema crônico que interfere no mercado de trabalho. A inexistência de projetos sinceros de reforma agrária impede a criação de opções de agricultura de subsistência, que diminuiriam o impacto do desemprego estrutural. Isso se dá em razão do retorno do projeto nacional agroexportador, de baixo valor agregado, e que exige a contínua expulsão dos pequenos proprietários do campo.

Há quem enxergue aspectos positivos no fracasso das políticas de emprego adotadas na década de 1990, como o Programa de Expansão e Melhoria da Qualidade de Vida do Trabalhador (PROEMPREGO), criado pela Resolução 113, de 01.08.1996 (BRASIL, 1996), do Conselho Deliberativo do Fundo de Amparo ao Trabalhador (CODEFAT). Afirma-se que: 
Por meio desses dispositivos vem se processando um consenso ideológico que favorece a ressignificação do trabalho como não direito. As próprias entidades sindicais passaram a consumir suas agendas para operacionalização de práticas de intermediação de mão de obra, qualificação e incentivo a cooperativas. Governos regionais de diferentes matizes ideológicos consagraram essas práticas. O Judiciário atuou abrindo jurisprudência para as práticas de informalização ou se detendo longe de fiscalizações mais apuradas, de modo que se formou uma elite ocupada em dar respostas operativas à ocupação, mesmo que o principal resultado fosse imaterial no sentido do consenso pela quase naturalização da informalização das relações de trabalho. O Estado como indutor dessa ressignificação do trabalho - ou seja, as mudanças nas relações de trabalho ocorrem com a ação decisiva do Estado (BARBOSA, 2008, p. 100. Grifo da autora).

Essa autora, com inusitada sinceridade para os padrões brasileiros, defende o ponto de vista de que a precarização do trabalho é a forma de resolver o problema do trabalho e elogia a preocupação das elites com o atingimento desses objetivos. Conclui que o próprio Estado, inclusive por meio do Poder Judiciário [v.g. Súmula 331 do TST (BRASIL, 1993], contribui para aquilo que denomina "ressignificação" do trabalho, basicamente um novo laissez-faire (cada trabalhador deve virar-se como puder, segundo o que the for oferecido), com o tempero brasileiro da informalidade.

A existência de grupos precários não é acidental nem é anticapitalista. A precariedade é resultado da força expansiva do próprio capital, e suas bases não conduzem a uma transformação da sociedade, mas a uma adaptação. A sociedade burguesa precisa "para conservar a si mesma, para permanecer idêntica a si mesma, para 'ser', expandir-se continuamente, prosseguir, lançar sempre para mais além os limites, não respeitar nenhum deles, não permanecer igual a si mesma" (ADORNO, 2009, p. 31). Não é possível imaginar que por meio da precariedade social do trabalho se encontrará limite para o consumo consciente e se obterá um meio ambiente sustentável.

O paradoxo do desenvolvimento sustentável é sua pretensão de preservar o desenvolvimento (a essência da sociedade burguesa e do modo de produção capitalista) e, ao mesmo tempo, preservar a natureza, como se ao desenvolvimento pudesse ser imposto algum limite. A antinomia a que Adorno $(2009$, p. 31) aponta é justamente que, concebida em um sistema, a sociedade burguesa, "no momento em que alcançasse um nível limite, em que não pudesse mais dispor sobre espaços não-capitalistas fora dela mesma, ela precisaria se suspender segundo seu conceito".

De fato, o Estado brasileiro se preocupou durante muito tempo em ressignificar o trabalho, mas para deixá-lo mais próximo das condições vigentes no século XIX. As políticas públicas mais difundidas na América Latina para tentar diminuir o impacto do desemprego 
são de duas ordens: primeira, o incentivo ao empreendedorismo; segunda, um tardio programa de renda mínima.

O empreendedorismo é uma ideologia fincada na ideia de que cada trabalhador pode se fazer por si próprio e que basta um pouco de dedicação, um pequeno capital e alguma qualificação técnica para que qualquer indivíduo se transforme em um empresário de sucesso, um capitalista emergente. Evidentemente, esse ideário não é novo, pois remonta ao liberalismo do século XVII, mas assumiu roupagens de política pública a partir de 1980. Uma demonstração disso está na criação do Serviço Brasileiro de Apoio às Microempresas (Sebrae), pelo artigo $8^{\circ}$ da Lei 8029, de 12.04.1990 (BRASIL, 1990c), combinado com o Decreto 99570, de 09.10.1990 (BRASIL, 1990a). Trata-se de um órgão autônomo cuja principal atividade tem sido a de ensinar os indivíduos a serem empreendedores. É justamente nesse contexto que, principalmente a partir do início do século XXI, tem sido incentivada a economia solidária, que assim pode ser definida:

\footnotetext{
A terminologia economia solidária pode servir para designar práticas econômicas populares que estão fora do assalariamento formal - como comércio ambulante, pequenas oficinas, serviços autônomos, artesanato, confecções de costura -, englobando ações que são individualizadas e outras que agrupam pessoas onde o sentido de coletividade precisa ser enfocado, provocando a solidariedade na produção da atividade econômica, propriamente (BARBOSA, 2008, p. 101. Grifo da autora).
}

Esses carpinteiros, costureiras, vendedores ambulantes, biscateiros, alçados à condição de autônomos pelas alterações verificadas no capitalismo contemporâneo, à de cooperados e de microempresários, não só vivem tão ou mais precariamente que os trabalhadores informais como também, principalmente, estão sob forte subordinação estrutural sob a esvoaçante capa da autonomia, razão pela qual raramente as microempresas duram mais de um ano. Embora seja verdade que uma parte do movimento da economia solidária aponte "para a formulação de uma nova cultura do trabalho em sentido gramsciano, tendo o trabalho como mediação educativa de novas práticas e subjetividades centradas no homem e em sua emancipação" (BARBOSA, 2008, p. 109), é certo que essa educação para a precariedade muito raramente consegue contentar seus felizes participantes, ou dar a eles alguma estabilidade emocional e econômica. Por isso, é comum os respectivos educadores, geralmente remunerados direta ou indiretamente pelos cofres públicos, surpreenderem-se com a manifestação do desejo desses autônomos de retornarem à prisão da carteira assinada. É quase impossível criar práticas econômicas coletivas se o fundamento ideológico desse processo está fincado no individualismo empreendedor, na precarização de todo trabalho e na mercantilização continuada de todo espaço vital. Como destaca Gorz (1995, p. 8): 
O problema é que na sociedade mercantil capitalista não permanece muito espaço para o desenvolvimento de novos e diversos tipos de comunidades microssociais baseadas sobre a colaboração voluntária e a codivisão dos projetos. Em regra, as necessidades são satisfeitas pela produção e pela troca dos bens e as comunidades fundadas sobre a participação devem limitar-se a ocupar os espaços vazios que nem a produção nem o Estado cuidam ou desejam ocupar. Por consequência, nos confrontamos com um déficit permanente de relações comunitárias ou - o que é equivalente - de integração e participação social.

O programa de renda mínima, por sua vez, é uma política pública mais consistente e tem impacto redistributivo, mas o seu ponto negativo é que, por ser dirigido ao indivíduo isolado, produz novos consumidores para o mercado, mas tem dificuldade em resolver os problemas mais profundos da divisão social do trabalho. Com efeito, os programas de renda mínima tendem a não adquirir o mínimo de capital simbólico que lhe dê estabilidade no espaço público. Mais uma vez, é Gorz (1995, p. 11) quem aponta o problema central:

\begin{abstract}
Se adquire a cidadania econômica somente mediante aquelas atividades que se desenvolvem como cidadãos, na esfera pública, em benefício de outros na sua condição de cidadãos; para que esses disso obtenham vantagem, enquanto cidadãos, e não como indivíduos singulares aos quais estejam ligados por particulares vínculos privados. Por exemplo, adquirirás cidadania econômica e legal mediante o trabalho no processo social de produção, produzindo bens ou tornando acessíveis serviços destinados a quem quer que seja, não somente a alguns aos quais estejam ligados por relações especiais. Adquirem-se direitos de cidadania cuidando de anciãos em uma casa de acolhimento ou trabalhando em uma escola para enfermeiros. Aqui estás a serviço de outros cidadãos como cidadão na esfera macrossocial e consideras de tudo normal que as obrigações que o teu trabalho comporta e o consenso que dele decorre sejam legalmente e socialmente sancionados.
\end{abstract}

Essa dificuldade, entretanto, parece requerer uma ressignificação política e jurídica dos mecanismos de renda mínima, pois as alterações do mundo capitalista industrializado exigem algum tipo de nova política pública, agora não mais voltada simplesmente ao trabalho, mas ao não trabalho. É o próprio Gorz (2003, p. 199-200) que, revendo sua posição anterior, sintetiza o ponto central:

\begin{abstract}
Quando o processo de produção exige cada vez menos trabalho e distribui cada vez menos salários, esta evidência, progressivamente, impõe a todos: não é mais possível reservar o direito à renda apenas às pessoas que ocupam um emprego, nem, sobretudo, fazer depender o nível de renda da quantidade de trabalho fornecida por cada um. Daí nasce a ideia de uma renda garantida independentemente do trabalho, ou da quantidade de trabalho, a todo cidadão e cidadã.
\end{abstract}

A história do trabalho no Brasil parece confirmar a necessidade de proteção àqueles que supostamente não trabalham (os autônomos estruturais), pois estes sempre estiveram jogados à própria sorte. 


\section{CONCLUSÃO}

As políticas públicas de trabalho brasileiras tiveram até recentemente o objetivo central de tornar mais barata a mão de obra, de modo a reforçar os mecanismos de dominação social. É necessário repensar essas políticas à luz das transformações operadas no sistema capitalista, que precisa, cada vez mais, de menos trabalho para se reproduzir. De outra parte, a crise ambiental coloca em contradição o próprio sistema produtivo e exige uma diminuição do trabalho social aplicado no processo industrial.

É necessário atribuir espaço público para atividades que ainda não possuem relevância simbólica, pois as alterações verificadas demandam novas formas de solidariedade social. O trabalho feminino não assalariado e os autônomos estruturalmente dependentes estão entre as atividades sem proteção social e que demandam novas políticas públicas que se desvinculem da ideologia liberal, a qual pensa o trabalho como primordial substância da dignidade humana e como única forma de acesso à cidadania. Nessa perspectiva, é necessário repensar e tornar estáveis e simbolicamente relevantes programas como os de renda social.

\section{REFERÊNCIAS}

ADORNO, Theodor W. Dialética negativa. Tradução Marco Antonio Casanova. Rio de Janeiro: Jorge Zahar, 2009.

ALVES, Giovanni. O novo (e precário) mundo do trabalho: reestruturação produtiva e crise do sindicalismo. São Paulo: Boitempo, 2000.

ALVES, Maria Aparecida; TAVARES, Maria Augusta. A dupla face da informalidade: "autonomia" ou precarização. In: Riqueza e miséria do trabalho no Brasil. ANTUNES, Ricardo (Org.). São Paulo: Boitempo, 2006, p. 425-44.

ANTUNES, Ricardo. Os sentidos do trabalho: ensaio sobre a afirmação e a negação do trabalho. São Paulo: Boitempo, 1999.

AZEVEDO, Célia Maria Marinho de. Onda negra, medo branco: o negro no imaginário das elites - século XIX. Rio de Janeiro: Paz e Terra, 1987.

BARBOSA, Rosangela Nair de Carvalho. Economia solidária: estratégias de governo no contexto da desregulamentação social do trabalho. In: SILVA, Maria Ozanira da Silva e; YAZBEK, Maria Carmelita. Políticas públicas de trabalho e renda no Brasil contemporâneo. $2^{\mathrm{a}}$ ed. São Paulo: Cortez, 2008, p. 90-129.

BOSI, Alfredo. Dialética da colonização. São Paulo: Cia. das Letras, 1992. 
BRASIL. Constituição da República Federativa do Brasil de 1988. Diário Oficial da República Federativa do Brasil, Brasília, DF, 05 out 1988. Disponível em: <http://www.planalto.gov.br/ccivil_03/constituicao/Constituicao.htm>. Acesso em: 12 set. 2013.

Decreto $\mathrm{n}^{\circ} 2.827$, de 15 de março de 1879. Dispondo o modo como deve ser feito o contrato de locação de serviços. Coleção de Leis do Império do Brasil - 1879, Página 11 Vol. 1 pt. I (Publicação Original). Disponível em: <http://www2.camara.leg.br/legin/fed/decret/1824-1899/decreto-2827-15-marco-1879547285-publicacaooriginal-62001-pl.html>. Acesso em: 12 set. 2013.

Decreto $\mathrm{n}^{\circ}$ 213, de 22 de fevereiro de 1890. Revoga todas as leis e disposições relativas aos contractos de locação de serviço agricola. Coleção de Leis do Brasil - 1890, Página 294 Vol. 1 fasc. $2^{\circ}$ (Publicação Original). Disponível em: <http://www2.camara.leg.br/legin/fed/decret/1824-1899/decreto-213-22-fevereiro-1890520791-publicacaooriginal-1-pe.html>. Acesso em: 12 set. 2013.

Decreto no 99.570, de 9 de outubro de 1990. Desvincula da Administração Pública Federal o Centro Brasileiro de Apoio à Pequena e Média Empresa (Cebrae), transformando-o em serviço social autônomo. Diário Oficial da União, Brasília, DF, 10 out. 1990. (1990a) Disponível em: <http://www.planalto.gov.br/ccivil_03/decreto/D99570.htm>. Acesso em: 12 set. 2013.

Decreto-Lei n. ${ }^{\circ}$ 5.452, de $1^{\circ}$ de maio de 1943. Aprova a Consolidação das Leis do Trabalho. Diário Oficial da União, Rio de Janeiro, DF, 9 ago. 1943. Disponível em: <http://www.planalto.gov.br/ccivil_03/decreto-lei/del5452.htm>. Acesso em: 12 set. 2013.

Decreto-Lei n ${ }^{\circ}$ 2.283, de 27 de fevereiro de 1986. Dispõe sobre a instituição da nova unidade do sistema monetário brasileiro, do Seguro-Desemprego e dá outras providências. Diário Oficial da União, Brasília, DF, 28 fev. 1986 (1986a). Disponível em: <http://www.planalto.gov.br/ccivil_03/decreto-lei/Del2283.htm>. Acesso em: 12 set. 2013.

Decreto-Lei $\mathrm{n}^{\circ}$ 2.284, de 10 de março de 1986. Mantém a nova unidade do sistema monetário brasileiro, o seguro-desemprego, amplia e consolida as medidas de combate à inflação. Diário Oficial da União, Brasília, DF, 11 mar. 1986, retificado em 12 mar. 1986 e em 13 mar. 1986 (1986b). Disponível em: <http://www.planalto.gov.br/ccivil_03/decretolei/del2284.htm>. Acesso em: 12 set. 2013.

Decreto-Lei no 4.048, de 22 de janeiro de 1942. Cria o Serviço Nacional de Aprendizagem dos Industriários (SENAI). Coleção de Leis do Brasil - 1942. Disponível em: <http://www.planalto.gov.br/ccivil_03/decreto-lei/1937-1946/Del4048.htm>. Acesso em: 12 set. 2013.

Decreto-Lei no 8.621, de 10 de janeiro de 1946. Dispõe sôbre a criação do Serviço Nacional de Aprendizagem Comercial e dá outras providências. Diário Oficial da União, Rio de Janeiro, DF, 12 jan. 1946. Disponível em: <http://www.planalto.gov.br/ccivil_03/decretolei/1937-1946/De18621.htm>. Acesso em: 12 set. 2013. 
Lei de 13 de setembro de 1830. Regula o contracto por escripto sobre prestação de serviços feitos por Brazileiro ou estrangeiro dentro ou fóra do Imperio. Coleção de Leis do Império do Brasil de 1830 Disponível em: <http://www2.camara.leg.br/legin/fed/lei_sn/1824-1899/lei-37984-13-setembro-1830565648-publicacaooriginal-89398-pl.html>. Acesso em: 12 set. 2013.

. Lei de 7 de novembro de 1831. Declara livres todos os escravos vindos de fôra do Imperio, e impõe penas aos importadores dos mesmos escravos. Coleção de Leis do Império do Brasil - 1831, Página 182 Vol. 1 pt I (Publicação Original). Disponível em: <http://www2.camara.leg.br/legin/fed/lei_sn/1824-1899/lei-37659-7-novembro-1831-564776publicacaooriginal-88704-pl.html>. Acesso em: 12 set. 2013.

. Lei $\mathrm{n}^{\circ} 108$, de 11 de outubro de 1837. Dando varias providencias sobre os Contractos de locação de serviços dos Colonos. Coleção de Leis do Império do Brasil - 1837, Página 76 Vol. 1 pt I (Publicação Original). Disponível em: <http://www2.camara.leg.br/legin/fed/lei/1824-1899/lei-108-11-outubro-1837-559407publicacaooriginal-85738-pl.html>. Acesso em: 12 set. 2013.

Lei $\mathrm{n}^{\circ} 2.040$, de 28 de setembro de 1871. Declara de condição livre os filhos de mulher escrava que nascerem desde a data desta lei, libertos os escravos da Nação e outros, e providencia sobre a criação e tratamento daquelles filhos menores e sobre a libertação annual de escravos. Coleção de Leis do Império do Brasil - 1871. Disponível em: <http://www.planalto.gov.br/ccivil_03/Leis/LIM/LIM2040.htm>. Acesso em: 12 set. 2013.

Lei $\mathrm{n}^{\circ} 3.071$, de $1^{\circ}$ de janeiro de 1916. Código Civil dos Estados Unidos do Brasil. Diário Oficial da União, Rio de Janeiro, DF, 5 jan. 1916. Disponível em: <http://www.planalto.gov.br/ccivil_03/leis/13071.htm>. Acesso em: 12 set. 2013.

. Lei $\mathrm{n}^{\circ} 3.270$, de 28 de setembro de 1885 . Regula a extincção gradual do elemento servil. Coleção de Leis do Império do Brasil - 1885, Página 14 Vol. 1 (Publicação Original). Disponível em: <http://www2.camara.leg.br/legin/fed/lei/1824-1899/lei-3270-28-setembro1885-543466-publicacaooriginal-53780-pl.html>. Acesso em: 12 set. 2013.

Lei no 5.107, de 13 de setembro de 1966. Cria o Fundo de Garantia do Tempo de Serviço, e dá outras providências. Diário Oficial da União, Brasília, DF, 13 set. 1966. Disponível em: <http://www.planalto.gov.br/ccivil_03/leis/L5107.htm>. Acesso em: 12 set. 2013.

Lei $\mathrm{n}^{\circ}$ 5.859, de 11 de dezembro de 1972. Dispõe sobre a profissão de empregado doméstico e dá outras providências. Diário Oficial da União, Brasília, DF, 12 dez. 1972. Disponível em: <http://www.planalto.gov.br/ccivil_03/leis/15859.htm>. Acesso em: 12 set. 2013.

. Lei ${ }^{\circ}$ 5.889, de 8 de junho de 1973. Estatui normas reguladoras do trabalho rural. Diário Oficial da União, Brasília, DF, 11 jun. 1973. Disponível em: <http://www.planalto.gov.br/ccivil_03/leis/15889.htm>. Acesso em: 12 set. 2013.

. Lei $\mathrm{n}^{\circ} 555$, de 25 de junho de 1850. Código Comercial. Coleção de Leis do Império do Brasil - 1850, T.11, pág. 57-238. Disponível em: <http://www.planalto.gov.br/ccivil_03/leis/10556-1850.htm>. Acesso em: 12 set. 2013. 
. Lei ${ }^{\circ} 7.998$, de 11 de janeiro de 1990. Regula o Programa do Seguro-Desemprego, o Abono Salarial, institui o Fundo de Amparo ao Trabalhador (FAT), e dá outras providências. Diário Oficial da União, Brasília, DF, 12 jan. 1990. (1990b) Disponível em: <http://www.planalto.gov.br/ccivil_03/leis/17998.htm>. Acesso em: 12 set. 2013.

Lei no 8.029, de 12 de abril de 1990. Dispõe sobre a extinção e dissolução de entidades da administração Pública Federal, e dá outras providências. Diário Oficial da União, Brasília, DF, 13 abr. 1990, retificado em 23 abr. 1990 (1990c). Disponível em: <http://www.planalto.gov.br/ccivil_03/leis/18029compilada.htm>. Acesso em: 12 set. 2013.

Ministério do Trabalho e Emprego. Resolução No 113 de 01 agosto de 1996. Aprova o conjunto de critérios e normas referentes ao PROEMPREGO. Diário Oficial da União, Brasília, DF, 9 ago. 1996. Disponível em: <http://portal.mte.gov.br/codefat/resolucao-n-113de-01-08-1996.htm>. Acesso em: 12 set. 2013.

Tribunal Superior do Trabalho. Súmula $\mathrm{n}^{\circ} 331$ do TST. Contrato de Prestação de Serviços. Legalidade. Diário Oficial da União, Brasília, DF, 21 dez. 1993. Disponível em: <http://www3.tst.jus.br/jurisprudencia/Sumulas_com_indice/Sumulas_Ind_301_350.html>. Acesso em: 12 set. 2013.

CARRIQUIRY, Silvana Arrarte. Os desafios das políticas de combate ao desemprego: algumas reflexões sobre experiências sociais. In: DIEESE (Org.). Emprego e desenvolvimento tecnológico: Brasil e contexto internacional. São Paulo: DIEESE, 1998, p. 237-60.

CHALHOUB, Sidney. Trabalho, lar e botequim: o cotidiano dos trabalhadores no Rio de Janeiro da belle époque. 2a . ed. Campinas: Unicamp, 2001.

COUTINHO, Aldacy Rachid. Direito do Trabalho: a passagem de um regime despótico para um regime hegemônico. In: COUTINHO, Aldacy Rachid; WALDRAFF, Célio Horst. Direito do Trabalho \& Direito Processual do Trabalho: temas atuais. Curitiba: Juruá, 1999.

FRANCO, Maria Sylvia de Carvalho. Homens livres na ordem escravocrata. $3^{\text {a }}$ ed. São Paulo: Kairós, 1983.

FRENCH, John D. Afogados em leis: a CLT e a cultura política dos trabalhadores brasileiros. São Paulo: Fundação Perseu Abramo, 2001.

GEBARA, Ademir. O mercado de trabalho livre no Brasil: 1871-1888. São Paulo: Brasiliense, 1986.

GEORGE, Susan. Effetto boomerang. In: GEORGE, Susan; PAPISCA, Antonio; MICARELli, Massimo. Un'economia che uccide. $2^{\mathrm{a}}$ ed. Città di Castello (Pg): Societa Cooperativa Editoriale L'altrapagina, 1997.

GOMES, Ângela de Castro. A invenção do trabalhismo. $2^{\mathrm{a}}$ ed. Rio de Janeiro: Relume Dumará, 1994.

GORZ, André. Metamorfoses do trabalho: crítica da razão econômica. Tradução Ana Montoia. $2^{a}$ ed. São Paulo: Annablume, 2007. (Título original: Métamorphoses du travail. Quête du sens: critique de la raison économique). 
Società, comunità e reddito di base. In: AZZARITI, Gaetano et al. Ai confini dello Stato sociale. Roma: Manifestolibri, 1995, p. 7-17.

KOWARICK, Lúcio. Trabalho e vadiagem: a origem do trabalho livre no Brasil. $2^{\mathrm{a}}$ ed. Rio de Janeiro: Paz e Terra, 1994.

LAMOUNIER, Maria Lúcia. Da escravidão ao trabalho livre: a lei de locação de serviços de 1879. Campinas: Papirus, 1988.

MARX, Karl. O capital: crítica da economia política. Tradução Reginaldo Sant'Anna. 23a ed. Rio de Janeiro: Civilização Brasileira, 2006, v. II.

MENDONÇA, Joseli Maria Nunes. Cenas de abolição: escravos e senhores no Parlamento e na Justiça. São Paulo: Perseu Abramo, 2001.

PARANHOS, Adalberto. O roubo da fala: origens da ideologia do trabalhismo no Brasil. São Paulo: Boitempo, 1999.

POCHMANN, Márcio. O emprego na globalização: a nova divisão internacional do trabalho e os caminhos que o Brasil escolheu. São Paulo: Boitempo, 2001.

Rumos da política do trabalho no Brasil. In: SILVA, Maria Ozanira da Silva e; YAZBEK, Maria Carmelita. Políticas públicas de trabalho e renda no Brasil contemporâneo. $2^{\mathrm{a}}$ ed. São Paulo: Cortez, 2008, p. 23-40.

POLANYI, Karl. A grande transformação: as origens de nossa época. Tradução Fanny Wrobel (Título original: The great transformation). $2^{\mathrm{a}}$ ed. Rio de Janeiro: Elsevier, 2000.

RODRIGUES, Edgar. Trabalho e conflito: pesquisa - 1906-1937. Rio de Janeiro: Arte Moderna, 1975.

SAMARA, Eni de Mesquita. Lavoura canavieira, trabalho livre e cotidiano. São Paulo: Edusp, 2005.

SILVA, Maria Ozanira da Silva e; YAZBEK, Maria Carmelita. Políticas públicas de trabalho e renda no Brasil contemporâneo. $2^{\mathrm{a}}$ ed. São Paulo: Cortez, 2008.

SOUZA, Jessé. A construção social da subcidadania: para uma sociologia política da modernidade periférica. Belo Horizonte: Editora UFMG, 2003.

SUPIOT, Alain. Homo juridicus: ensaio sobre a função antropológica do direito. Tradução Maria Ermantina de Almeida Prado Galvão. São Paulo: Martins Fontes, 2007.

TAYLOR, Charles. As fontes do self: a construção da identidade moderna. Tradução Adail Ubirajara Sobral; Dinah de Abreu Azevedo. 2a ed. São Paulo: Loyola, 2005.

VIANNA, Francisco José de Oliveira. Direito do trabalho e democracia social. São Paulo: José Olympio, 1951. 
VIANNA, Luiz Werneck. Caminhos e descaminhos da revolução passiva à brasileira. Revista Dados. Rio de Janeiro, v. 39, $\mathrm{n}^{\circ}$. 3, 1996. Disponível em: $<$ http://www.scielo.br/scielo.php?pid=S0011-52581996000300004\&script=sci_arttext\& tlng=en>. Acesso em: 12 set. 2013.

\section{WORK: PUBLIC POLICIES IN BRAZIL}

ABSTRACT: The Brazilian public policies related to labor were usually guided by the attempt to supply cheap and plentiful manpower, firstly for rural elites, then for the incipient industrial capital. Both slavery and immigration policies were linked to this purpose. However, the subsequent social legislation took on the contradictory character of social and economic transformations of the twentieth century and from its authoritarian bases acquired an emancipatory content. The nowadays fragmentation and reduction of the work, both quantitative and qualitative, requires new forms of social protection, in addition to the wagebased citizenship, in order to incorporate those supposedly autonomous workers, which are found under deep structural dependency. It is necessary to allocate public space for activities that still do not have symbolic relevance and that demand new forms of social solidarity. It is in this perspective that social income programs should be designed.

KEYWORDS: Public policies. Social income. Work. 